\title{
The economics of low emission zones
}

Maria Börjesson, Anne Bastian and Jonas Eliasson

The self-archived postprint version of this journal article is available at Linköping University Institutional Repository (DiVA):

http://urn.kb.se/resolve?urn=urn:nbn:se:liu:diva-181053

N.B.: When citing this work, cite the original publication.

Börjesson, M., Bastian, A., Eliasson, J., (2021), The economics of low emission zones, Transportation Research Part A, 153, 99-114. https://doi.org/10.1016/j.tra.2021.08.016

Original publication available at:

https://doi.org/10.1016/j.tra.2021.08.016

Copyright: Elsevier

http://www.elsevier.com/

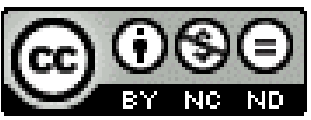




\title{
The Economics of Low Emission Zones
}

Maria Börjesson'1, Anne Bastian², Jonas Eliasson³

${ }^{1}$ Swedish National Road and Transport Research Institute and KTH Royal Institute of Technology, Stockholm, Sweden

${ }^{2}$ City of Stockholm

${ }^{3}$ Linköping University and Swedish National Transport Administration

\begin{abstract}
This paper provides two microeconomic models that derive the social cost of a low emission zone (LEZ) for light vehicles. We apply the models to a proposed LEZ for light vehicles in Stockholm, which would prohibit diesel cars of Euro 5 or lower and gasoline cars of Euro 4 or lower in the inner city $\left(25 \mathrm{~km}^{2}\right)$ and conduct a cost-benefit analysis of the proposed LEZ. The first model is based on how an increase in user cost impacts traffic volumes in the inner city. This rather conventional user cost calculation of drivers' loss requires however some strong assumptions. The second model shows that drivers' losses can be calculated based on price changes observed on the used car market. Our empirical results indicate that the welfare loss resulting from the two models are of the same magnitude. The forecast benefits of the LEZ consist primarily of air quality improvements leading to health benefits. Even if our empirical results must be interpreted with caution, it seems clear that the costs substantially outweigh the benefits in this case study.
\end{abstract}

Keywords: Dieselgate, low emission zones, environmental zones, cost-benefit analysis, car market. 


\section{INTRODUCTION}

The evidence of harmful effects of nitrogen dioxide $\left(\mathrm{NO}_{2}\right)$ has increased in recent years (Atkinson et al., 2018; Lelieveld et al., 2015; Silva Raquel A. et al., 2016). The EU's main policy instrument to reduce harmful vehicle exhaust emissions, including $\mathrm{NO}_{2}$ emissions, is to gradually tighten the Euro standards regulating new vehicles' maximal emissions. In certain urban areas with high pollution levels, however, this gradual process to reduce emissions is sometimes considered to be too slow. This has led several cities to introduce or consider low-emission zones (LEZ), where vehicles driving in the zone must meet certain Euro standards. While earlier European policies have primarily targeted particle matter pollution (Wolff and Perry, 2010), the focus on reducing nitrogen oxide emissions has meant that the LEZ:s which are now considered would ban relatively new vehicles. For instance, in 2019 Milan introduced a $129 \mathrm{~km}^{2}$ large LEZ, banning diesel cars of Euro 4 or lower (CLARS, 2019; POLIS et al., 2020), and the restrictions are planned to be tightened gradually. But while there is a relatively large literature assessing health benefits from reduced $\mathrm{NO}_{\mathrm{x}}$ air pollution (Beelen et al., 2014; Faustini et al., 2014), no previous paper has consistently computed the adaptation costs of LEZ:s for light vehicles. The aim of this paper is to develop a methodology for computing the social costs of an LEZ, and then apply the evaluation framework to a proposed LEZ in Stockholm, and compare them to the benefits.

Our case study calculates the social costs and benefits of a proposed LEZ in Stockholm, which would prohibit diesel cars of Euro 5 or lower and gasoline cars of Euro 4 or lower from driving in the inner city. The proposed LEZ would cover the inner city which is roughly $25 \mathrm{~km}^{2}$ and would coincide with the area enclosed by the congestion charging cordon (with some negligible differences). Stockholm provides a unique opportunity to compute social costs and benefits due to the microdata available from the congestion charging system. This provides visiting frequencies to the inner city by vehicle type, and also an estimate of the cost sensitivity of traffic, based on the reactions when the congestion charges were increased in 2016.

The social costs consist primarily of adaptation costs for drivers of banned cars, who either have to refrain from driving in the LEZ or trade their car for an LEZ-compliant one. We derive and propose two microeconomic models for calculating the social cost of an LEZ. The first model is based on how an increase in user cost impacts traffic volumes in the inner city. This rather conventional user cost calculation of drivers' loss requires however rather strong assumptions in the application: that cars cannot be traded, that the demand function for driving in the zone is linear, and that there is no option value associated with owning a LEZ-compliant car. For this reason, we derive a second model, showing how drivers' losses can be calculated based on observed price changes on the used car market. The Stockholm LEZ proposal was much discussed in media for a long time, creating an impression that it was highly likely to be introduced. Although no decision had been made, the media coverage apparently affected prices of used cars. Prices of used diesel cars that would be banned in the LEZ (model years 2014 and earlier) sank by over $€ 400$ on average in Sweden, apparently in anticipation of the LEZ introduction. We show how the drivers' total loss can be inferred from these price changes.

Considering the complexity of data needed to produce empirical estimates, our estimates of drivers' welfare losses must be interpreted with caution. Still, our calculation provides an order of magnitude of the cost which no other studies have provided. Moreover, a key contribution of the paper is to provide theoretically consistent microeconomic models 
that can be applied to any city to derive the social costs of an LEZ. Our empirical results indicate that the welfare loss resulting from the two models are of the same magnitude.

The forecasted benefits of the LEZ consist primarily of air quality improvements leading to health benefits. We use results obtained by the Stockholm Environmental Administration, using a combination of an atmospheric emission dispersion model and an exposure/health relationship. The benefits of the LEZ are relatively small, for three reasons: light vehicles banned by the LEZ are responsible only for a small share of $\mathrm{NO}_{2}$ levels; Stockholm has relatively low atmospheric $\mathrm{NO}_{2}$ levels; $\mathrm{NO}_{2}$ levels are predicted to decline quickly over time even without the LEZ, due to the natural renewal of the vehicle fleet.

We find that the social benefits of the air quality improvements are less than a tenth of the social cost. Enforcement costs also add to the social costs of an LEZ (Milan, for instance, uses camera enforcement), although we do not attempt to quantify them. Even if our empirical results must be interpreted with caution, it seems clear that the costs substantially outweigh the benefits in this case study.

The effects of an LEZ will, however, vary depending on the city and the design of the zone. Effects depend on the initial setting (geography, other pollution sources, vehicle fleet composition, vehicle market context, travel alternatives), the LEZ design (banned vehicles, timing, zone size and location, exemptions), and the degree of enforcement. The air quality in Stockholm already meets the EU air quality regulation for average pollution levels, and also most of the additional, stricter Swedish regulations. A contributing reason to this is probably that an LEZ for heavy vehicles was introduced in Stockholm already in 1996.

Air quality effects of LEZs are difficult to determine ex-post. Meteorological variations call for long measurement periods (Pasquier and Andre, 2017) and LEZ benefits quickly diminish due to natural vehicle fleet renewal (Carslaw and Beevers, 2002). Wolff (2014) concludes that Germany's largest LEZs reduced particle pollution, while smaller zones had small or no benefits. Johansson et al. (2014) corroborate this relationship between zone size and effectiveness. Malina and Scheffler (2015), Ellison et al. (2013), Morfeld et al. (2014), and Holman et al. (2015) conclude that some LEZs had small air quality benefits while others had none. Effectiveness also depends on which pollutant is measured. Particle pollution mostly depends on total traffic volume (Amato, 2018), and OECD (2020) report that because electric cars are heavier than other cars, is unlikely that they will emit less particles. Nitrogen oxide pollution, however, depends on the specific traffic composition and its emission characteristics.

Section 2 derives the microeconomic models for assessing the social cost. Section 3 reports the empirical results derived from applying the models. Section 4 includes the estimation of the health benefits. Section 5 assesses the impact on the fuel composition of the sales of new cars, and some assessment of the impact on carbon emissions. Section 6 lays out the storyline of the proposal in Stockholm, as a basis for understanding the response and timing of this response to the LEZ proposal on the used car market. Section 7 concludes.

\section{DRIVERS' WELFARE LOSS OF THE LEZ}

Drivers' welfare loss can be calculated either by using an estimated demand function for trips to the LEZ, or by measuring price changes on the used car market. In this section, we describe the two approaches. In the first approach, we estimate a demand function 
for trips to the LEZ based on the response to the introduction and subsequent increase of the Stockholm congestion charges, since the proposed LEZ coincides with the area enclosed by the congestion charging cordon. Based on this demand function the Marshallian consumer surplus can be calculated. Since the welfare calculation is based on travel demand, it is akin to the standard "measuring benefits on the road" approach in transport economics. A necessary assumption in this approach is that drivers cannot buy or sell cars on the used car market in response to the LEZ. This assumption might be reasonable if transaction costs are prohibitively high, or if all car owners have similar preferences. In the latter case, all drivers suffer a similar welfare loss from owning a banned car, so there are no incentives to trade cars in response to the LEZ. In order to calculate the loss of consumer surplus, we also need to extrapolate the demand curve beyond the observation points all the way to zero demand.

Obviously, these are strong assumptions. In the second approach, we relax these assumptions and instead calculate the welfare loss based on price changes on the used car market. In the second subsection, we show how the welfare loss can be calculated based on observable price changes. If the car market were perfect, these price changes would precisely reflect the welfare loss, without the restrictive assumptions in the first approach. The crucial assumption in this "car market" approach is that car owners are perfectly informed, i.e. that they can accurately assess the welfare loss of owning a banned car with the LEZ in place. As we shall see, this assumption may be questionable in the Stockholm case, since the communication of what cars would actually be banned in the LEZ was not very clear. This is discussed in detail in the paper's final section.

The two approaches will not necessarily yield the same outcome even if the restrictive assumptions are relaxed, since the assumptions are mutually exclusive. The key assumption in the first approach is that drivers cannot trade cars between them in response to the LEZ, so the change in generalized travel costs captures the entire consumer loss. The key assumption in the second approach is, on the contrary, that owners of compliant and banned cars do trade cars as a response to the LEZ, and the price changes on the used car market hence reflect the consumer loss. Moreover, there may exist so-called option values of owning an LEZ-compliant car, over and above the standard consumer surplus calculated based on observed travel demand. Option values may arise because car owners are uncertain about their future demand for travelling to the LEZ since there is a significant cost of later replacing a banned car. Ideally, this uncertainty should be accounted for when calculating the consumer surplus empirically, but since we cannot do this, we will not capture a possible option value and might thus underestimate the consumer surplus. In both welfare calculations, we assume that there are no other price changes. ${ }^{1}$

\subsection{Measuring drivers' welfare loss using the travel demand function ("on the road")}

Let $t$ be the number of car trips (in the following we let "cars" include all light vehicles) per day to the LEZ area. Let $p(t)$ be the inverse demand function for such trips and assume that it is linear

$$
p(t)=\alpha+\beta t .
$$

\footnotetext{
${ }^{1}$ For instance, we assume that the generalized cost of travelling with public transport, and the deficit for public transport authority, stay unaffected by any possible modal shift. In rush hour the market share for public transport is already so much higher than for car, so any such modal shift would only increase in the public transport patronage marginally.
} 
Without loss of generality, we can set $p=0$ before the LEZ is implemented. This means that the Marshallian consumer surplus of LEZ trips is $\frac{\beta t^{2}}{2}$ per day. Assume that it is not possible for car owners to trade cars with each other (not even within a household) ${ }^{2}$, and that there are no systematic differences in preferences between owners of banned cars and owners of compliant cars. Since cars cannot be traded, owners of banned cars will lose their entire consumer surplus when the LEZ is introduced. The variable $\theta_{y}$ is the share of trips to the LEZ made by banned cars in year $y$. This share will decline over time due to the natural renewal of the car fleet, even if the LEZ is not introduced. The present value of the total welfare loss for owners of banned cars becomes

$$
\Delta W=\frac{d \beta t^{2}}{2} \sum_{y=1}^{Y} \theta_{y} \frac{(1+g)^{y}(1+b)^{y}}{(1+r)^{y}}
$$

where $Y$ is the total number of years where banned cars remain in the car fleet, $r$ is the social discount rate, $g$ is the traffic growth per year (due to for example population or economic growth), $b$ is the GDP/capita growth per year (we adopt the conventional assumption that valuations grow proportionally to the GDP/capita growth), and $d$ is the number of days per year.

Measuring the welfare loss based on an estimated travel demand function ("on the road"), as above, rests on two assumptions. First, that owners of compliant and banned cars do not trade cars with each other; if they did, those with high willingness to pay for driving in the LEZ would trade cars with those with low willingness to pay. This would reduce the overall welfare loss, so assuming that drivers cannot trade cars with each other will tend to overestimate the welfare loss. To demonstrate the point, take Stockholm as example. There were 340,000 owners of banned cars and 900000 owners of compliant cars who traveled to the proposed LEZ in 2018, whereas there were 2 million compliant cars in Sweden. Assuming that the used car market is in equilibrium before the LEZ and that there are no transaction costs and that all car owners are identical aside from their preference for driving in the LEZ, the welfare loss could in principle be zero, if the 340,000 owners of banned cars could swap cars with the 1.1 million compliant car owners who never traveled to the LEZ during a year.

Second, we can only observe a small part of the demand curve but must extrapolate it all the way to zero demand to calculate the loss of the entire consumer surplus of LEZ trips. In the derivation above we assumed that the demand is linear. This assumption is likely to lead to an underestimation of the welfare loss. A convex demand function would result in a larger loss of consumer surplus, and there is some evidence that the demand function is indeed convex. At the two occasions when the congestion charges were increased, the observed price elasticity was substantially smaller than the price elasticity observed when the charges were first introduced.

\subsection{Measuring car owners' loss on the car market}

As concluded above, the "on the road" approach can either overestimate or underestimate the welfare loss. In this section we will therefore calculate the welfare loss using price changes on used cars, which eliminates these problems. This "car market" approach assumes that used cars can be bought and sold: owners of banned cars can sell their car and buy a compliant one in order to still be able to travel to the LEZ. Such trading of used cars will affect the prices, since the supply of used cars is essentially

2 This is a reasonable assumption given that only 24 percent of the households have more than one car in the County of Stockholm. 
fixed. ${ }^{3}$ In other words, the LEZ will reduce the service quality of banned cars, implying that the prices of these used cars fall. Since the supply of banned cars is essentially fixed in the short run, banned car prices will fall until aggregate demand equals supply again, meaning that the price fall exactly compensate the reduction of service quality.

Let index $i$ denote the type of car. In our empirical analysis, we will only distinguish car types by fuel and year model. Let $q_{i}$ be a measure of the service quality of a car of type $i$, capturing all kinds of quality aspects including the car's fuel economy, remaining lifetime etc. Let $N_{i}$ be the fixed supply of used cars of type $i$, and $p_{i}$ the corresponding price. Demands for cars $D_{i}$ are determined by a representative individual solving the following optimization problem

$$
\begin{gathered}
\max _{\left\{D_{i}\right\}, x} u\left(\left\{D_{i}\right\} \mid\left\{q_{i}\right\}\right)+x \\
\text { s.t. } \sum_{i} D_{i} p_{i}+x=I
\end{gathered}
$$

where $u\left(\left\{D_{i}\right\} \mid\left\{q_{i}\right\}\right)$ is the representative individual's utility of owning cars $\left\{D_{i}\right\}$, given their service qualities $\left\{q_{i}\right\}, x$ is a numeraire good and $I$ is income. Preferences of the representative individual are thus represented by a quasi-linear utility function, summing the utility derived from the sub-utility function for car ownership and the utility derived from other goods $(x)$, see for instance Varian (1992). The lagrangean is

$$
L=u\left(\left\{D_{i}\right\} \mid\left\{q_{i}\right\}\right)+x-\lambda\left(\Sigma_{i} D_{i} p_{i}+x-I\right)
$$

and the optimality conditions are

$$
\frac{d L}{d x}=1-\lambda=0 \rightarrow \lambda=1
$$

and

$$
u_{i}^{\prime}-p_{i}=0 \forall i
$$

where $u_{i}^{\prime}$ means $\frac{\partial u}{\partial D_{i}}$. Let $v\left(\left\{p_{i}\right\},\left\{q_{i}\right\}, I\right)$ be the indirect utility function of the representative individual. Market prices are determined by the market equilibrium constraints

$$
D_{i}(\mathbf{p})=N_{i} \forall i
$$

When the LEZ is introduced, some cars are banned. Let $B$ be the index set of banned cars and $C$ the index set of compliant cars. The LEZ decreases the service qualities $q_{i}$ of banned cars $i \in B$. Since the supply of each type $N_{i}$ of used cars is fixed, prices will have to adjust to satisfy the equilibrium constraints (7.). Call the change in service qualities $d q_{i}$ and the changes in prices $d p_{i}$. Differentiate $v\left(\left\{p_{i}\right\},\left\{q_{i}\right\}, I\right)$ and add the car price changes (since revenues from used car sales also accrue to the representative individual) to get the welfare change $d W$

$$
d W=\sum_{i} \frac{\partial v}{\partial p_{i}} d p_{i}+\frac{\partial v}{\partial q_{i}} d q_{i}+\sum_{i} N_{i} d p_{i}=
$$

\footnotetext{
3 We believe that this assumption is reasonable since any possible impact on scrapping, used car exports
} and imports, or sales of new cars on the margin would be small compared to the large existing vehicle fleet. 


$$
\text { \{use Roy's identity: } \begin{aligned}
\frac{\partial v}{\partial p_{i}} & \left.=-D_{i}, D_{i}=N_{i}, \text { and } d q_{i}=0 \forall i \in C\right\} \\
& =\sum_{i \in B} \frac{\partial v}{\partial q_{i}} d q_{i}
\end{aligned}
$$

This shows that the price changes cancel out, since supply is fixed - they are only transfers between car owners. The welfare loss hence only depends on the decreased service quality for banned cars. We know from the envelope theorem that $\sum_{i \in B} \frac{d v}{d q_{i}} d q_{i}=$ $\sum_{i \in B} \frac{d L}{d q_{i}} d q_{i}$, and so using (4.) we have

$$
\begin{gathered}
d W=\sum_{i \in B} \frac{d v}{d q_{i}} d q_{i}=\sum_{i \in B} \frac{d L}{d q_{i}} d q_{i}= \\
=\sum_{i \in B} u_{i}^{\prime} \frac{d D_{i}}{d p_{i}} \frac{d p_{i}}{d q_{i}} d q_{i}-\left(\frac{d D_{i}}{d p_{i}} \frac{d p_{i}}{d q_{i}} p_{i}+D_{i} \frac{d p_{i}}{d q_{i}}\right) d q_{i}= \\
=\{\text { use the optimality conditions (6.) })= \\
=\sum_{i \in B} p_{i} \frac{d D_{i}}{d p_{i}} \frac{d p_{i}}{d q_{i}} d q_{i}-\left(\frac{d D_{i}}{d p_{i}} \frac{d p_{i}}{d q_{i}} p_{i}+D_{i} \frac{d p_{i}}{d q_{i}}\right) d q_{i}= \\
=\sum_{i \in B} D_{i} \frac{d p_{i}}{d q_{i}} d q_{i}=\sum_{i \in B} D_{i} d p_{i} .
\end{gathered}
$$

This means that we can express the welfare loss from (8.) in terms of the price changes of banned cars.

\section{RESULTS}

In this section, we calculate the welfare loss for the LEZ proposed to be introduced in Stockholm in 2022, based on the two models defined in 2.1 and 2.2. The proposed LEZ requires that gasoline cars meet the Euro 5 standard and that diesel cars meet the Euro 6 standard.

\subsection{Welfare loss measured through the demand curve}

Stockholm introduced congestion charges in 2006 (Börjesson et al., 2012; Eliasson, 2008). The charging system then consisted of a cordon around the inner city, encompassing the LEZ analyzed in this paper, see Figure 1 . When the charges were introduced, the number of trips across the cordon decreased by slightly more than $20 \%$ during charged hours (6:30-18:30 weekdays). The charges were increased in 2016, especially during the morning and afternoon peak hours, which further reduced the daily number of trips across the cordon. We use this latter increase to estimate linear demand curves for private trips (privately owned cars) and professional trips (light goods vehicles, taxis, and cars owned by firms). 


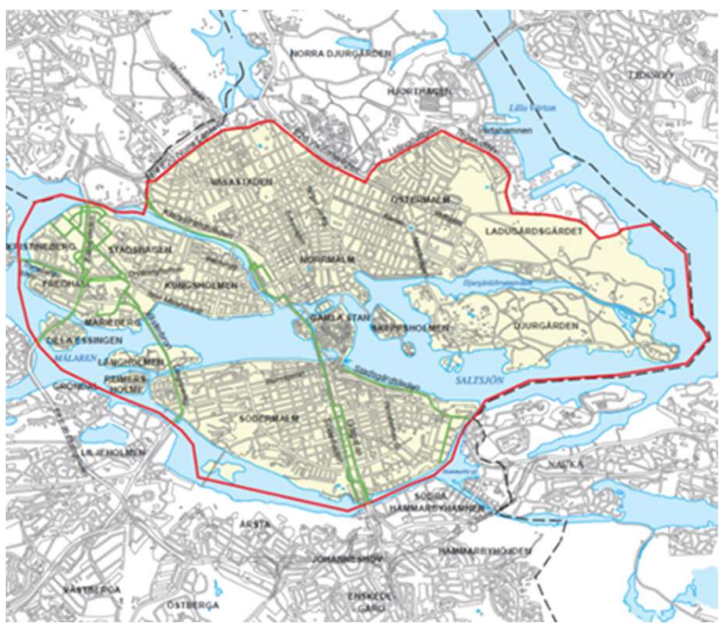

Figure 1: The proposed Stockholm LEZ.

Figure 2 shows how the number of private and professional trips per day across the cordon responded to the congestion charges. The congestion charge is paid per passage in either direction and varies across the day. The average charge per trip was $1.1 €$ during the period 2006-2015. When the charges were introduced, the number of private trips per day across the cordon decreased from 348000 to 212000 per day, and the number of professional trips per day decreased from 304000 to 274000 . The number of trips per day across the cordon then stayed virtually unchanged 4 until charges were increased in 2016, resulting in an average charge per trip of $1.8 €$, which decreased the number of private trips to 189000 per day and the number of professional trips to 264000 per day. The dashed lines show our extrapolation of a linear relationship based on the reaction to the 2016 charge increase.

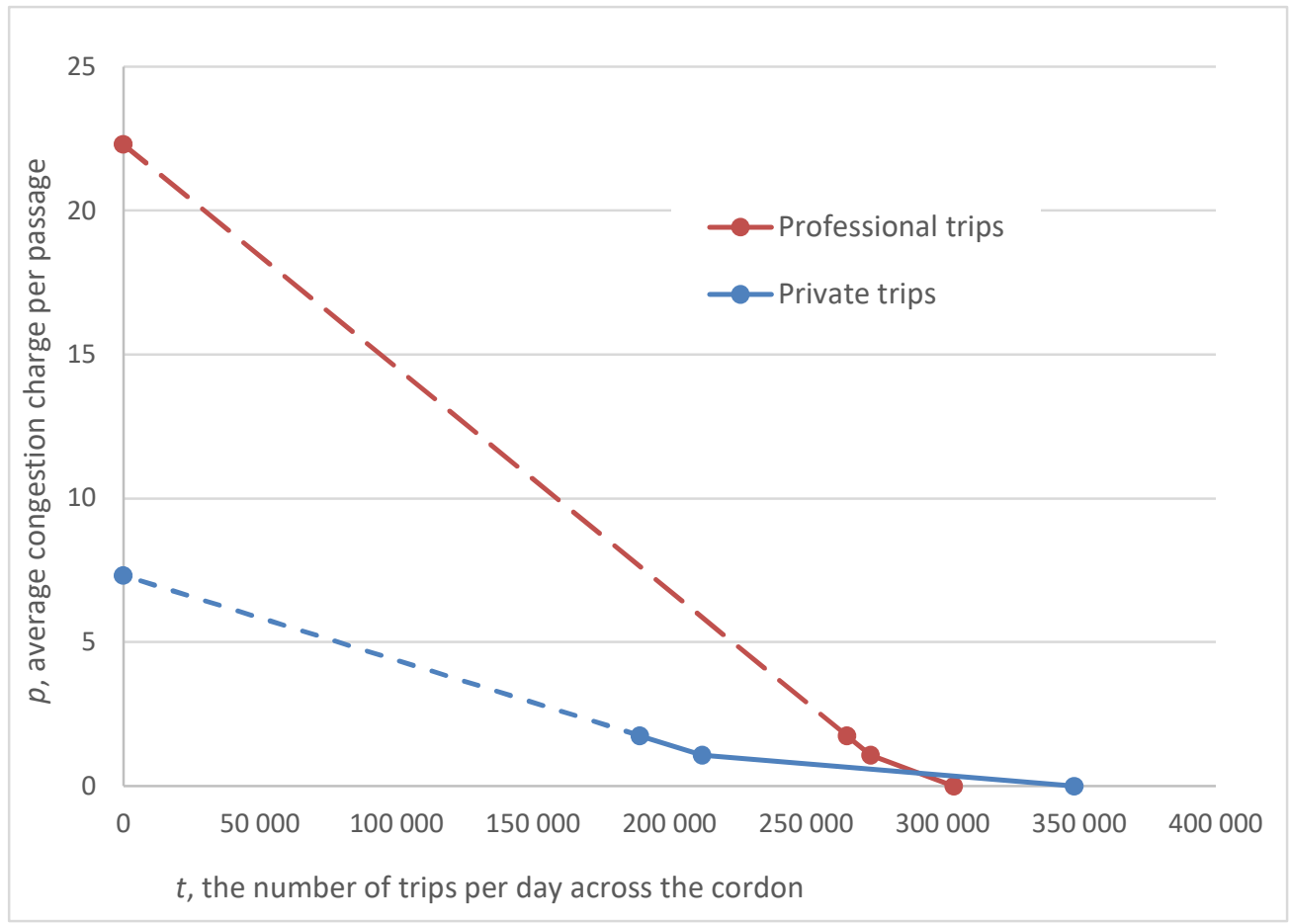

\footnotetext{
${ }^{4}$ Potential effects of traffic growth from economic growth have been cancelled out by some reduction of exemptions (Börjesson and Kristoffersson, 2018).
} 


\begin{tabular}{|l|c|c|c|c|c|c|}
\hline & $\begin{array}{c}\text { Before the } \\
\text { charges }\end{array}$ & 2015 & 2016 & $\begin{array}{c}m=\frac{\beta t}{2} \\
€\end{array}$ & $\begin{array}{c}\beta \\
€ / \text { car }\end{array}$ & $\begin{array}{c}\alpha=\max \text { wtp } \\
€\end{array}$ \\
\hline $\begin{array}{l}\text { \# private trips } \\
\text { per day, } t\end{array}$ & 348000 & 212000 & 189000 & 2.8 & -0.00004 & 7.32 \\
\hline $\begin{array}{l}\text { \# professional } \\
\text { trips per day, } t\end{array}$ & 304000 & 274000 & 265000 & 10.3 & -0.00011 & 22.29 \\
\hline Charge, $p$ & 0 & 1.1 & 1.8 & & & \\
\hline
\end{tabular}

Figure 2: Inverse demand functions estimated from the response in the number of trips to the increase of the average congestion charge (Börjesson et al., 2012; Börjesson and Kristoffersson, 2018). ${ }^{5}$

Assuming linear demand functions, the demand curve intersects the y-axis at $7.3 €$ for private trips and at $22.3 €$ for professional trips. The average adaptation cost per trip $\left(m=\frac{\beta t}{2}\right)$ is therefore $(7.3-1.8) / 2=2.8 €$ for private trips and $(22.3-1.8)=10.3 €$ for professional trips.

From 2.1 we have that the present value of the total welfare loss $\Delta W=$ $d \frac{\beta t^{2}}{2} \sum_{y=1}^{Y} \theta_{y} \frac{(1+g)^{y}(1+b)^{y}}{(1+r)^{y}}$. (differing between private and professional trips), where $y=1$ for 2022, the year the zone is introduced. We assume that the share of banned passages is negligible in 2030, such that $Y=9$. We assume that the adaptation cost $m$ increases proportionally to GDP/capita, assumed to increase yearly by $b=1.5 \%$ and a social discount rate of $r=3.5 \%$ (following Swedish CBA guidelines). The yearly traffic growth $g$ is taken to be $1 \%$, close to the historical average. The number of days per year $d=320$ (not 365 because traffic volumes are lower during weekends and summer vacation).

The share of passages which is banned by the LEZ, $\theta_{y}$, will vary over time because older (banned) vehicles leave the car fleet and are replaced by new compliant cars. The share $\theta_{y}$ for a future year $y$ is based on a prediction of the composition of the light vehicle fleet in the county (by age, Euro class and fuel), and is different for for private and professional vehicles. Taking the current fleet composition as a starting point, the fleet composition in future years is calculated based on assumptions of future sales and scrapping of old cars. These assumptions are based on historical rates of changes of different vehicle types, disregarding any possible impact on the vehicle fleet in response to the LEZ. Specifically, the yearly changes in the number of vehicles by type observed 2013-2017 are assumed to persist in 2018-2030. The yearly reduction rate of a car type is taken to be the reduction rate of the corresponding car type of the previous euro model, four years earlier (since the euro models come roughly every four years). So for instance, Euro 4 diesel cars owned by a company decreased by 18 percent between 2016 and 2017, and we therefore assume that Euro 5 diesel cars owned by a company decrease by 18 percent between 2020 and 2021. We also assume that no cars remain in the fleet after 20 years. For instance, Euro 3 cars (produced before 2006) are all assumed to be scrapped by 2026. We further assume that the size of the car and light truck fleets increase by 1 percent yearly (the observed yearly increase 2010-2020), and that the new cars entering the fleet year $y$ is distributed according to the Traffic Analysis forecast (see section 5) for this year.

\footnotetext{
5 The 2015 and 2016 figures for number of trips are average daily counts over a month in November 2015 and February 2016. The figures for "Before the charges" are calculated from the 2015 figures and adjusted with the percentage change in the number of trips observed when the charges were first introduced in 2006 .
} 
Finally, we take into account that the trip frequency varies among vehicle types, for instance that older cars are used less than new cars. For this reason, we apply a trip frequency weight, proportional to the trip frequency to the LEZ by vehicle type, received from the city of Stockholm. ${ }^{6}$ To calculate the share of banned trips $\theta_{y}$, for private and professional traffic respectively, we use the forecast total size of the vehicle fleet weighted by trip frequency, and the forecast number of banned cars weighted by their trip frequency, for the year y. We assume full compliance with the LEZ regulations. In practice, this might be difficult and expensive to enforce, so the welfare loss might be smaller than we predict (but so will the benefits in that case).

The resulting share of banned cars are shown in the first columns of Table 1 . It shows that in the first year of the zone $2022,30 \%$ of the private trips and $16 \%$ of the professional trips would be banned. In subsequent years, the shares of non-compliant vehicles and trips decrease, due to the natural renewal of the vehicle fleet. In 2030, only $7 \%$ of the private and $3 \%$ of the professional trips are non-compliant. Table 1 then adds the discounted consumer loss by year for private and professional trips. Adding up the total welfare loss for all banned vehicles 2022-2030 we get 849 million $€$.

Table 1: Banned share of passages, $\theta_{y}$, and welfare loss by year, $\Delta W_{y}=d \frac{\beta t^{2}}{2} \theta_{y} \frac{(1+g)^{y}(1+b)^{y}}{(1+r)^{y}}$, for professional and private trips.

\begin{tabular}{|l|r|r|r|r|r||}
\hline & $\begin{array}{c}\theta_{y} \\
\text { Private } \\
\%\end{array}$ & $\begin{array}{c}\theta_{y} \\
\text { Professional } \\
\%\end{array}$ & $\begin{array}{c}\Delta W_{y} \\
\text { Private } \\
\text { million } €\end{array}$ & $\begin{array}{c}\Delta W_{y} \\
\text { Professional } \\
\text { million } €\end{array}$ & $\begin{array}{c}\Delta W_{y} \\
\text { All trips } \\
\text { million } €\end{array}$ \\
\hline 2020 & $42 \%$ & $23 \%$ & 71 & 203 & 275 \\
\hline 2021 & $35 \%$ & $19 \%$ & 60 & 170 & 230 \\
\hline \hline $2022, \mathrm{y}=1$ & $30 \%$ & $16 \%$ & 50 & 141 & 192 \\
\hline $2023, \mathrm{y}=2$ & $25 \%$ & $13 \%$ & 42 & 110 & 152 \\
\hline $2024, \mathrm{y}=3$ & $22 \%$ & $11 \%$ & 36 & 71 & 127 \\
\hline $2025, \mathrm{y}=4$ & $19 \%$ & $9 \%$ & 31 & 53 & 108 \\
\hline $2026, \mathrm{y}=5$ & $12 \%$ & $6 \%$ & 19 & 45 & 61 \\
\hline $2027, \mathrm{y}=6$ & $10 \%$ & $5 \%$ & 17 & 38 & 53 \\
\hline $2028, \mathrm{y}=7$ & $9 \%$ & $5 \%$ & 15 & 33 & 45 \\
\hline $2029, \mathrm{y}=8$ & $8 \%$ & $4 \%$ & 13 & 28 & 39 \\
\hline $2030, \mathrm{y}=9$ & $7 \%$ & $3 \%$ & 11 & & 849 \\
\hline \hline Tot $\sum_{y=1}^{9} \Delta W_{y}$ & & & & & 53 \\
\hline
\end{tabular}

The results depend to some extent on parameter assumptions, such as discount rate, traffic growth and valuation growth. Doubling the social discount rate $r$ from $3.5 \%$ to $7 \%$ reduces the welfare loss to 682 million $€$, and so does not alter the magnitude of the welfare loss.

The assumption that demand curves are linear matter more for the results. If demand curves are in fact convex rather than linear, the true welfare loss will be higher than the one calculated above. As shown in Figure 2, the demand curves do in fact appear to be convex. If we, instead of extrapolating linear demand curves from the two left-most observation points, extrapolate quadratic demand curves going through all three observation points, the calculated welfare losses increase substantially. The welfare loss

${ }^{6}$ We assume that the trip frequency weight to the LEZ by vehicle type equals the milage weight for the city of Stockholm (by vehicle type). 
for private cars almost doubles (from $2.8 €$ to $4.7 €$ per passage), while the welfare loss for professional vehicles increases more than fourfold (from $10.3 €$ to $42.2 €$ per vehicle). 7 This gives a total welfare loss 3.5 times larger than for the case with linearly extrapolated demand curves. Clearly, the possible convexity of the demand curves matters considerably for the results. On the other hand, since the on-the-road approach disregards the possibility of adapting by switching cars, it will tend to overestimate the welfare loss for precisely the drivers who would suffer large welfare losses.

\subsection{Measuring the welfare loss on the used car market}

We continue by computing the welfare loss using the car-market model defined in 2.2, resulting in (9.) $d W=\sum_{i \in B} \frac{\partial v}{\partial q_{i}} d q_{i}=\sum_{i \in B} D_{i} d p_{i}$. We integrate $D_{i} d p_{i}$ from initial to final prices. Since demands are equal to the constant supply by assumption, the integral collapses to the price changes weighted by the number of cars of type $i$.

$$
\Delta W=\sum_{i} \int D_{i} d p_{i}=\sum_{i \in B} \int_{p_{i}^{0}}^{p_{i}^{1}} D_{i} d s=\sum_{i \in B} D_{i}\left(p_{i}^{1}-p_{i}^{0}\right)
$$

To compute this empirically, we use average prices from online advertisements of used cars for sales in Sweden published between January-June 2017 (before the LEZ introduction was communicated) and March-June 2018 (after the LEZ introduction was communicated). The public debate of the LEZ proposal started in July 2017 (see further section 6).

The calculation is shown in Table 2. The first column shows the number of banned cars by type registered in Sweden. The second and third columns show the prices observed in 2017 (March-June) and 2018, respectively. The final column calculates the welfare loss according to (11.). The welfare loss for banned gasoline cars is 86 million $€$, and the welfare loss for banned diesel cars is 535 million $€$, making up a total of 621 million $€$. This is of the same magnitude as the welfare loss obtained through the on-the-road approach above, which yielded a total welfare loss of 849 million $€$.

The price fall for cars that would be banned in the proposed LEZ, analyzed so far, was expected and is consistent with our theory. Less expected, however, was that the price of younger diesel cars that would not be banned in the proposed LEZ also decreased. The price drop of these newer compliant diesel cars also implies a real welfare loss. The LEZ proposal apparently contributed to decreasing the market value of these cars, for whatever reason, and this constitutes a tangible welfare loss even if these cars are in fact LEZ compliant. If this loss is added to the welfare loss above, it more than doubles to 1318 million $€$. This additional loss will obviously not be captured by the on-the-road approach but should be added to the loss. However, decision makers in other cities might be able to avoid or reduce this loss by communicating what the LEZ regulations will in fact mean more clearly (see section 6).

Table 2: Fleet size by car type (model year and fuel), and car prices in 2018 and 2017. Note that each row compares prices of cars of the same age, i.e. 2018 prices of model year 2015

\footnotetext{
${ }^{7}$ Assuming that the demand functions are exponential functions on the form $p=a b^{t}$, calibrated to the two leftmost data points in, results in a more than 10 times larger loss of consumer surplus than when assuming linear demand functions.
} 
are compared to 2017 prices of model year 2014 and so on. Total welfare change by car type is computed by $D_{i}\left(p_{i}^{1}-p_{i}^{0}\right)$ and summed over car types.

\begin{tabular}{|c|c|c|c|c|c|}
\hline 1 & $\begin{array}{l}\text { Year } \\
\text { model } \\
\text { (in } \\
2018, \\
\text { see note } \\
\text { in } \\
\text { caption) }\end{array}$ & $\begin{array}{c}\text { Number of } \\
\text { banned } \\
\text { cars in } \\
\text { Sweden } \\
\boldsymbol{D}_{\boldsymbol{i}}\end{array}$ & $\begin{array}{c}\text { Price } \\
\text { observed } \\
2018 \\
\boldsymbol{p}_{\boldsymbol{i}}^{\mathbf{1}} \\
€\end{array}$ & $\begin{array}{c}\text { Price observed } 2017 \\
\text { for cars with } \\
\text { corresponding age } \\
\text { (see note in caption) } \\
\boldsymbol{p}_{\boldsymbol{i}}^{\mathbf{0}} \\
€\end{array}$ & $\begin{array}{c}\boldsymbol{D}_{\boldsymbol{i}}\left(\boldsymbol{p}_{\boldsymbol{i}}^{\mathbf{1}}-\boldsymbol{p}_{\boldsymbol{i}}^{\mathbf{0}}\right) \\
\quad \text { million } €\end{array}$ \\
\hline \multicolumn{6}{|c|}{ Gasoline } \\
\hline EURO3 & -05 & 247527 & 3590 & 3797 & -51 \\
\hline EURO4 & -06 & 219318 & 4489 & 4260 & 50 \\
\hline EURO4 & -07 & 184301 & 5556 & 5295 & 48 \\
\hline EURO4 & -08 & 114515 & 5980 & 6636 & -75 \\
\hline EURO4 & -09 & 87926 & 7324 & 7089 & 21 \\
\hline EURO4 & -10 & 108228 & 7803 & 8534 & -79 \\
\hline sum & & & & & -86 \\
\hline \multicolumn{6}{|c|}{ Diesel } \\
\hline EURO4 & -06 & 61325 & 4570 & 5075 & -31 \\
\hline EURO4 & -07 & 113564 & 4924 & 5468 & -62 \\
\hline EURO4 & -08 & 97165 & 5869 & 6314 & -43 \\
\hline EURO4 & -08 & 91183 & 6759 & 7025 & -24 \\
\hline EURO4 & -09 & 154282 & 7724 & 9119 & -215 \\
\hline EURO5 & -10 & 195153 & 11622 & 9268 & 460 \\
\hline EURO5 & -11 & 195419 & 12354 & 14181 & -357 \\
\hline EURO5 & -13 & 175438 & 13908 & 14363 & -80 \\
\hline EURO5 & -14 & 188034 & 17641 & 18613 & -183 \\
\hline sum & & & & & -535 \\
\hline EURO6 & -15 & 206400 & 19850 & 21366 & -313 \\
\hline EURO6 & -16 & 201057 & 23835 & 24851 & -204 \\
\hline EURO6 & -17 & 191068 & 25712 & 26648 & -179 \\
\hline
\end{tabular}

Figure 3 provides a possible explanation for why the prices of the used cars reacted in the entire country and not only in Stockholm. Of all banned cars that visit the LEZ at least once during a year, a large share visits the LEZ only rarely by a large number of different cars. Conversely, a relatively small share of all cars that visit the LEZ during a year make up the absolute majority of trips: $81 \%$ of the trips are made by only $23 \%$ of all vehicles that visit the LEZ during a year. The remaining $77 \%$ of the vehicles thus make only $19 \%$ of the trips. While these trips might be few, our welfare calculation suggests that the welfare loss of not being able to make them at all is significant. In other words, although the number of trips is few for many car owners, the few trips that are made, or the option to be able to make them, are valued highly by them.

Moreover, the cumulative frequency shows that many drivers with a very small contribution to $\mathrm{NO}_{\mathrm{x}}$ pollution (because they visit infrequently) will be punished rather heavily. For this reason, a pricing policy would be a more efficient policy than the LEZ regulation for light vehicles, and perhaps also a fairer policy in the sense that drivers are 
punished in proportion to their contribution to emission levels. It is also possible that the LEZ could have an appreciable, although transient, effect on traffic volumes and thus on congestion, depending on the adaption mechanisms. As shown in Table 1, 30 percent of all private visits to the LEZ would be banned during the first year (2022). However, the impact on congestion rapidly declines over time due to the natural vehicle renewal of the vehicles. Car trading would also tend to erode any possible congestion reduction, since car owners with a higher willingness to pay for driving in the zone can trade their banned car for a compliant one.

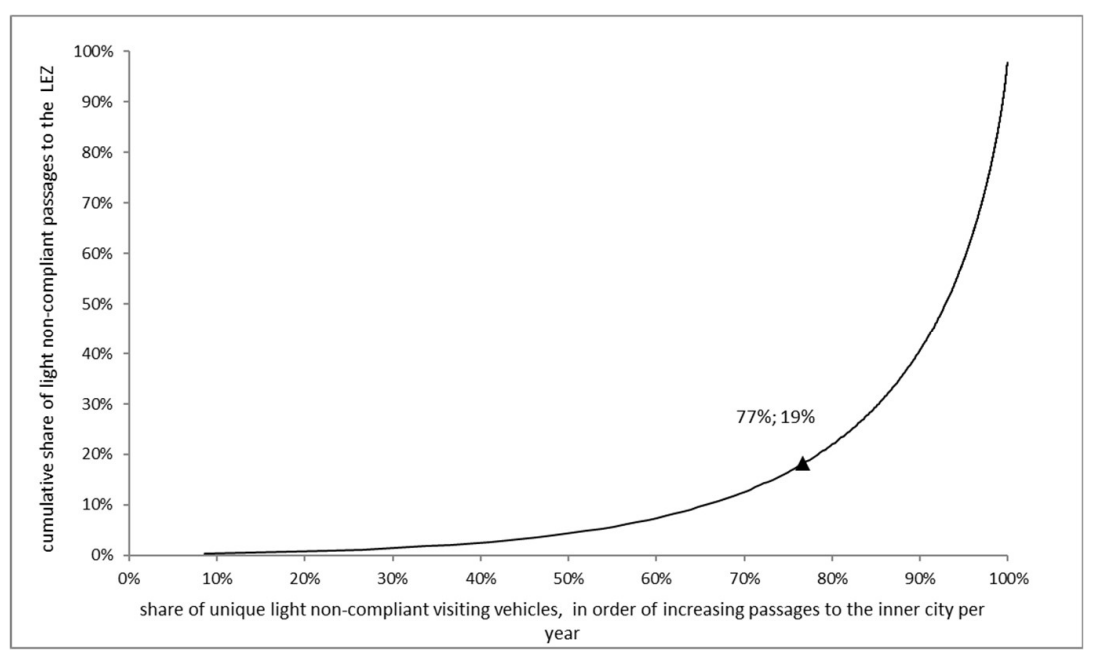

Figure 3: The cumulative share of non-compliant passages to the inner city made by the $x$ share of non-compliant unique light vehicles (out of all unique light non-compliant vehicles visiting the zone at least once) with the lowest trip frequency to the LEZ.

Note that the vehicle price changes that we use are ex ante changes, in the sense that the proposed LEZ had not been implemented, only proposed and announced, when the price changes were observed. Using these price effects to calculate the consumer loss from an actual implementation of the LEZ may result in over- or underestimation of the consumer loss, because the vehicle owners may over- or underestimate how the policy would affect them if it were implemented. It is very difficult to know how large this error is in our case. On the other hand, the observed price changes in response to the announcement represent a real welfare loss. The problem we face resembles the problem when calculating the consumer surplus of a new metro from changes in land prices precisely because it is difficult to know the moment when the consumer gain is perfectly internalized by the land market. We would however argue that it is easier to approximate the moment when the consumer loss is internalized by the car market in the LEZ case than in the metro case, simply because a metro takes years or decades from decision to opening and also because a metro project introduces traffic disturbances and noise during the building process.

\section{BENEFITS: AIR QUALITY AND HEALTH}

In this section, effects on air quality and health are summarized, resulting in a calculated social benefit. The calculation of the health effects is based on NOx pollution levels, since particle pollution mostly depends on total traffic volume (Amato, 2018; OECD, 2020). 
Stockholm already meets the EU air quality regulation for average pollution levels, and also most of the additional, stricter Swedish regulations. On one street in the inner city (Hornsgatan), however, $\mathrm{NO}_{2}$ levels exceed Swedish regulations for maximal hourly and daily levels ${ }^{8}$. This good air quality is partly due relatively low urban background pollution levels, and partly due to the existing LEZ for heavy vehicles, requiring heavy vehicles to meet the Euro V standard since 2017 and the Euro VI standard from 2021. The light-vehicle LEZ proposal might have been inspired not only by air quality problems but also by the "dieselgate" scandal in 2015 , when it was revealed that many diesel cars' emissions of nitrogen oxides were far above the Euro standard in real driving conditions (Anenberg et al., 2017; Brand, 2016).

To calculate the effect of the LEZ on pollution levels, we first construct a baseline scenario by keeping the prediction of the evolution of the light vehicle fleet composition in the county described in section 3.1. To construct an LEZ scenario, we assume that for all trips made by banned vehicles completely or partially in the LEZ, the banned vehicles are replaced by compliant vehicles according to Table 3 . These replacements can be a result of the combination of some driving as before but trading their car, and some refraining from driving in the LEZ being replaced with new drivers using the freed-up road space. We thus assume full compliance with the LEZ regulations, and that the LEZ policy does not impact the composition of the car fleet (since the car fleet remain constant in both scenarios).

Table 3: Assumed changes in the composition of light traffic within the LEZ in year 2022, LEZ scenario vs. baseline scenario, given 100\% compliance with the policy.

\begin{tabular}{|c|c|c|}
\hline \multicolumn{2}{|l|}{$\begin{array}{l}\text { baseline scenario, vehicle kilometres travelled in the } \\
\text { zone 2022 by: }\end{array}$} & diesel Euro 6d \\
\hline \multirow{2}{*}{ passenger car } & diesel Euro 5 & gasoline Euro 5 \\
\cline { 2 - 3 } & all Euro 0-4 & diesel Euro 6d \\
\hline \multirow{3}{*}{ light goods vehicle } & diesel Euro 4-5 & diesel Euro 6a-b \\
\cline { 2 - 3 } & diesel Euro 0-3 & gasoline Euro 5 \\
\cline { 2 - 3 } & gasoline Euro 0-4 & dine LEZ scenario with: \\
\hline
\end{tabular}

The next step is to calculate the reduction of NOx emissions by this change in traffic composition. We use the emission characteristics from the Handbook of Emission Factors 3.3 (HBEFA, 2017) shown in Table 4. This version of HBEFA is updated to reflect the actual, higher NOx emissions from new diesel cars uncovered by "dieselgate".

Table 4: Emission of NOx, $\mathrm{g} / \mathrm{km}$, from HBEFA3.3. Note the much tighter restrictions on NOx emissions in the Euro $6 d$ and Euro VI standards compared to Euro 5 and Euro V.

\begin{tabular}{|c|c|c|c|c|c|c|c|c|}
\hline & \multicolumn{9}{|c|}{ Light vehicles } & \multicolumn{4}{c|}{ Heavy vehicles } \\
\hline $\begin{array}{c}\text { NOx } \\
\mathrm{g} / \mathrm{km}\end{array}$ & $\begin{array}{c}\text { Euro 0-3 } \\
\text { (first } \\
\text { registered } \\
\text { before 2006) }\end{array}$ & $\begin{array}{c}\text { Euro 4 } \\
\text { (first } \\
\text { registered } \\
\text { after } \\
2006)\end{array}$ & $\begin{array}{c}\text { Euro 5 } \\
\text { (first } \\
\text { registered } \\
\text { after } \\
\text { 2011) }\end{array}$ & $\begin{array}{c}\text { Euro 6a-b } \\
\text { (first } \\
\text { registered } \\
\text { after } \\
2015)\end{array}$ & $\begin{array}{c}\text { Euro 6d } \\
\text { (first } \\
\text { registered } \\
\text { after } \\
\text { 2019) }\end{array}$ & $\begin{array}{c}\text { Euro IV } \\
\text { (heavy } \\
\text { vehicles } \\
\text { first } \\
\text { registered } \\
\text { after 2006) }\end{array}$ & $\begin{array}{c}\text { Euro V } \\
\text { (heavy } \\
\text { vehicles } \\
\text { first } \\
\text { registered } \\
\text { after 2009) }\end{array}$ & $\begin{array}{c}\text { Euro VI } \\
\text { (heavy } \\
\text { vehicles } \\
\text { first } \\
\text { registered } \\
\text { after 2014) }\end{array}$ \\
\hline $\begin{array}{c}\text { Gasolin } \\
\text { e }\end{array}$ & 0.39 & 0.08 & 0.04 & 0.04 & & & & \\
\hline Diesel & 0.82 & 0.73 & 1.04 & 0.56 & 0.15 & 11.57 & 11.04 & 0.98 \\
\hline
\end{tabular}

\footnotetext{
${ }^{8}$ According to Swedish regulations, the number of times per year that the hourly average $\mathrm{NO}_{2}$ level exceeds $90 \mu \mathrm{g} / \mathrm{m}^{3}$ must be less 175 , and the number of times per year that the daily average $\mathrm{NO}_{2}$ level exceeds $60 \mu \mathrm{g} / \mathrm{m}^{3}$ must be less 7 days per year. In 2018, the corresponding number of exceedances were 185 and 13 (SLB Analys, 2019).
} 
Next, the effect of the change in emissions on air pollution concentration levels and population exposure is calculated using dispersion and exposure models. The dispersion model is a meteorological simulation model, simulating the atmospheric dispersion of pollutant emissions from all sources, and can hence be used to simulate the effect of the change in emissions resulting from the LEZ. Pollution sources include detailed data on the Stockholm street network, with traffic volumes and vehicle composition modelled for every link. The dispersion model has a $100 \times 100$ meter spatial resolution, and simulates atmospheric concentration levels of pollutants on the full street network of the Stockholm County (Johansson et al., 2009). It takes into account factors affecting NOx dispersion such as the roughness of buildings and trees and the differences in ventilation conditions across streets. The NOx concentrations in the baseline and LEZ scenario were computed two meters above the ground for the full Stockholm county. The exposure model then calculates the population-weighted average exposure to NOx, using data on residential population by $100 \times 100$-meter square. Finally, a relationship between average NOx exposure and mortality was used to calculate the effect of the change in exposure concentration on average mortality. This relationship, taken from Nafstad et al. (2004) and previously used e.g. in Johansson et al. (2009), assumes an 8\% increase in mortality for every $10 \mu \mathrm{g} / \mathrm{m}^{3}$ increase in the population-weighted NOx exposure level.

In summary, this means that the number of saved life-years ${ }^{9}$ resulting from the LEZ introduction is calculated as

$$
\Delta N=\Delta C \times R R \times B L M \times P,
$$

where $\Delta N$ is the number of saved life-years, $\Delta C$ the difference in population-weighted NOx exposure $\left(\mu \mathrm{g} / \mathrm{m}^{3}\right)$ between the baseline and LEZ scenario, $R R$ is the exposure/mortality effect, $B L M$ is the baseline number of deaths of natural causes by age group, and $P$ is total population in the Stockholm County. For 2022 the number of saved life years is computed to be $N=130$ years. Note that saved life years occur later than the reduction of the pollution that caused them.

The calculation for the entire county refers to the year 2022, but we need the effect of the reduced NOx exposure for all the years for which the LEZ has an impact. For this reason, we calculate how the change in vehicle characteristics in the years 2022-2030 affect NOx concentration levels on Stockholm's most polluted street Hornsgatan. We then assume that total health benefits in the county for subsequent years change proportionally to the calculated change in NOx concentration levels on Hornsgatan.

The first column of Table 5 shows the computed reduction of NOx concentration on Hornsgatan for the years 2022-2030. The reduction of NOx concentration on Hornsgatan is $\Delta c_{2022}=10 \mathrm{mg} / \mathrm{m}^{3}$ in 2022 , and we have from above that the number of saved life years in the county in 2022 was $\Delta N_{2022}=130$ years. If $\Delta c_{y}$ is the reduction in concentration on Hornsgatan in year $y$ versus the baseline scenario, the number of saved statistical life years in the county in year $y$ is $\Delta N_{2022} \frac{\Delta c_{y}}{\Delta c_{2022}}$, which is shown in the second column of Table 5 .

Each saved life year is valued at 0.13 million $€$ (2018 prices) according to Swedish guidelines (Swedish Environmental Protection Agency, 2017). As in the calculation of the welfare loss, we apply a discount rate $r$ of 3.5\%, a GDP/capita growth $b$ of $1.5 \%$ and traffic growth $g$ of $1 \%$. From this we calculate the present value of the benefit in the final column. The total emissions reduction of the LEZ, assuming full compliance, is estimated

\footnotetext{
${ }^{9}$ The model assumes that one lost life is equivalent to 13 lost life years.
} 
to save 668 statistical life years. The corresponding net present value of the health benefits is approximately 58 million $€$. As before, the net present value depends on the assumed parameters: for example, doubling the social discount rate from $3.5 \%$ to $7 \%$ reduces the welfare loss to 47 million $€$.

Table 5: Calculation of the benefit of a reduction in NOx exposure due to the LEZ, 2018 price level.

\begin{tabular}{|l|r|r|r|}
\hline Year & $\begin{array}{l}\text { Reduction in annual } \\
\text { average NOx } \\
\text { concentration on } \\
\text { Hornsgatan }\left(\mu \mathrm{g} / \mathrm{m}^{3}\right):\end{array}$ & $\begin{array}{l}\text { Saved statistical life years in } \\
\text { Stockholm county }\end{array}$ & $\begin{array}{l}\text { Benefit, million } € \text {, present } \\
\text { value 2018 }\end{array}$ \\
\hline 2022 & 15 & 130 & 112 \\
\hline 2023 & 13 & 99 & 10 \\
\hline 2024 & 12 & 88 & 9 \\
\hline 2025 & 10 & 59 & 8 \\
\hline 2026 & 7 & 53 & 5 \\
\hline 2027 & 6 & 47 & 4 \\
\hline 2028 & 6 & 43 & 4 \\
\hline 2029 & 5 & 38 & 3 \\
\hline 2030 & 5 & 668 & 3 \\
\hline Sum & & 58 \\
\hline
\end{tabular}

\section{EFFECTS ON CARBON EMISSIONS AND OTHER EXTERNALITIES}

There are also indications that the suggested LEZ impacts greenhouse gas emissions by increasing the demand for new gasoline cars and reducing the demand for diesel cars among consumers buying new cars (note that the welfare calculation in sections 2-3 only deals with used cars and not new). A shift from diesel to gasoline cars increases carbon emissions, since a new gasoline car emits approximately $25 \%$ more carbon dioxide per kilometre than a diesel car of equal size (O'Driscoll et al., 2018). The diesel share of new cars fell from $49 \%$ in 2017 to $38 \%$ in 2018, while the gasoline share increased from $46 \%$ in 2017 to $54 \%$ in 2018.

To assess the impact on carbon emissions from an increased gasoline share among new cars induced by the LEZ proposal, we compare sales of new diesel cars in 2018 to a forecast of the diesel share published in April 2017 by Transport Analysis (2017). This forecast was based on observed trends and decided policies at the time, considering the "dieselgate" effect and planned policy changes ${ }^{10}$ on car sales. They predicted a declining trend in the sales of diesel cars. However, the forecast did not account for the public debate of the LEZ proposal, which started in July 2017 (see section 6). This means that the difference between the forecast and the actual 2018 outcome regarding the diesel cars to the LEZ message conveyed to car buyers from July 2017 is likely to be an effect of the LEZ proposal. This is of course uncertain but might serve as an approximation.

The forecast predicted that the share of new diesel cars sold in Sweden in 2018 would be $44 \%$, compared to the actual 38\% (see Table 6). Sales of BEV (Battery Electric Vehicle) and PHEV (Plug-in Hybrid Electric Vehicle) were approximately 2 percent lower than in the forecast. Instead, the share of gasoline cars increased to 54\%, compared to the forecast $46 \%$. A similar difference between outcome and forecast appeared again in 2019. In 2020 the share of diesel cars decreased even further compared to the forecast, whereas the sales of gasoline cars decline were in line with the forecast. BEV and PHEV increased substantially due to increased supply of electric cars as well as bonuses and

${ }^{10}$ Bonus-Malus of new cars was introduced in July 2018, implying that cars with low carbon emissions receive a bonus whereas cars with higher emissions must pay a punitive tax for three years. 
the EU requirement that the average emissions of each manufacturer's total sales in Europe must not exceed 95 grams per km for new passenger cars in 2021.

Table 6: Forecast (in April 2017) shares of gasoline and diesel cars among new cars and observed shares for Sweden and the Stockholm county.

\begin{tabular}{|l|r|r|r|r|r|r|}
\hline & \multicolumn{2}{l|}{$\begin{array}{l}\text { Sweden, forecast } \\
\text { issued in April } 2017\end{array}$} & \multicolumn{2}{l|}{ Sweden, outcome } & \multicolumn{2}{l|}{$\begin{array}{l}\text { Stockholm County, } \\
\text { outcome }\end{array}$} \\
\hline & Gasoline $^{*}$ & Diesel & Gasoline $^{*}$ & Diesel & Gasoline $^{*}$ & Diesel \\
\hline 2017 & $44 \%$ & $49 \%$ & $46 \%$ & $49 \%$ & $37 \%$ & $55 \%$ \\
\hline 2018 & $46 \%$ & $44 \%$ & $54 \%$ & $38 \%$ & $45 \%$ & $41 \%$ \\
\hline 2019 & $47 \%$ & $39 \%$ & $56 \%$ & $32 \%$ & $45 \%$ & $37 \%$ \\
\hline 2020 & $46 \%$ & $33 \%$ & $46 \%$ & $22 \%$ & $35 \%$ & $22 \%$ \\
\hline
\end{tabular}

* Including hybrid electric vehicle (HEV)

Appendix A makes a rough calculation of the increase in carbon emissions resulting from the increased share of gasoline cars relative to diesel cars, apparently triggered by the LEZ. Evidently, these calculations must be based on assumptions regarding whether the decrease in demand for new diesel cars, which would in fact be compliant with current regulations, will attenuate. Replacing new diesel cars with gasoline cars increases carbon emissions over the full life cycle of the cars, since gasoline cars emit more $\mathrm{CO}_{2}$ per km (all else equal). Depending on the assumptions, we find that the switch from diesel to gasoline cars caused by car buyers' anticipation of a Stockholm LEZ cause total $\mathrm{CO}_{2}$ emissions during the period 2017-2045 to increase by 2-6 million tons. The lower figure results if diesel car sales revert to the baseline trend after 2022. The higher figure results if the fall in diesel car sales continues after 2022, and if the large share of biofuels in diesel is taken into account. As a comparison, this is equivalent to $15-45 \%$ of current yearly emissions from the entire Swedish transport sector (although of course spread out over a longer time period).

We judge that other possible external costs arising from replacing diesel with gasoline cars are small because the NOx emissions from Euro 6d standard diesel cars are small (see Table 4). Effects on tax revenue and the internalization of carbon emissions are also approximately zero. A higher fuel tax on gasoline than on diesel (which many countries have) is cancelled out by a higher vehicle tax for diesel cars in Sweden. ${ }^{11}$ A shift from diesel to gasoline will not impact consumer surplus either, because the lower fuel cost of diesel cars is cancelled out by a higher capital cost.

\section{COMMUNICATING WITH THE PUBLIC}

The idea of legislation allowing cities to introduce LEZ:s for light vehicles had been suggested for many years, among others by the city of Stockholm. (The possibility to introduce LEZ:s for heavy vehicles had been introduced already in the 1990's, and several cities had heavy vehicle LEZ:s since many years.) In December 2015, the national government gave an assignment to the Swedish Transportation Agency, the authority responsible for traffic-related legislation, to draft a proposal for such legislation. The agency presented a legislation proposal in January 2017, which would allow cities to introduce an LEZ for light vehicles in an area of their choice. The definition of such an

11 The vehicle tax is for many common cars $€ 200-250$ higher per year for the diesel version than the gasoline version of the car. The tax on diesel is $€ 0.22$ lower per litre than the tax on gasoline. Assuming a yearly driving distance of $13000 \mathrm{~km}$ and that the gasoline car uses $40 \%$ more fuel (O’Driscoll et al., 2018), the fuel tax per year is €280 higher for the gasoline car. 
LEZ would be nationally regulated, however, as a zone only allowing diesel cars fulfilling the Euro 6 standard and gasoline cars fulfilling the Euro 5 standard. Together with the proposed legislation, the Transportation Agency also presented a case study of a light vehicle LEZ encompassing Stockholm's inner city (roughly $25 \mathrm{~km}^{2}$ ), analyzing effects, costs and benefits (Transportstyrelsen, 2017) (none of the authors of the present paper were involved in that study). Although the study's methodology was debatable in certain aspects, the conclusion clearly showed that societal costs were vastly higher than the benefits. The proposal was sent to the government, and also to the city of Stockholm (among others) for consultation.

The city of Stockholm answered in March 2017 that the city was positive to giving cities the possibility to introduce light vehicle LEZ:s if they so chose. On the other hand, the city stressed that before any such decision, benefits and costs of such an LEZ had to be further analyzed. The city also recommended that the regulation of an LEZ would gradually become stricter, eventually banning all diesel cars below the Euro 6c standard.

The national government did not comment on the proposed legislation or the consultation report from Stockholm, so it was unclear whether any LEZ legislation would in fact be introduced. So far, media reports had been rather few. But in July 2017, the LEZ issue exploded in the media when Stockholm's vice mayor for transportation stated that he wanted an LEZ in Stockholm, banning all diesel cars from Stockholm's inner city - not just older ones, as in the Transportation Agency's proposal, and not mentioning gasoline cars. The media unanimously presented this as if a complete ban on all diesel cars in Stockholm was highly likely to happen. A typical quote from Mitt $i$, the dominating local newspaper (July 4, 201712): "Have you recently bought a diesel car? You might regret that now. If the new LEZ:s are introduced, diesel cars will be banned in Stockholm's inner city from 2020. Vice mayor for transportation Daniel Helldén dissuades Stockholmers considering a new car from getting a diesel car. Says Helldén: 'Don't buy a diesel car and if you have one, don't drive it in the inner city. I understand that people who have bought diesels feel deceived, but we have to think about the health of stockholmers'." Similar articles appeared in, for example, Sweden's largest newspaper Aftonbladet (headline "Diesel ban likely in Stockholm", July 11 201713) and largest morning newspaper Dagens Nyheter (headline "Diesel cars may be banned in Stockholm's inner city", July 7 201714). Many newspaper articles followed, including editorials, opinion pieces and more news stories.

As noted, the legislation proposed by the Transportation Agency would in fact allow Euro 6 diesels, i.e. all diesels after 2015, in an LEZ, but this fact was usually lost in the media reporting. Moreover, it was clear that Stockholm's transportation vice-mayor wanted to ban all diesel cars. Since the legislation was now being prepared by the national government, it was uncertain how an LEZ would be in fact defined in the final legislation - whether it would follow the Transportation Agency's proposal, or some other, gradually stricter regulation as proposed by Stockholm's official response, or whether it would ban all diesel cars but perhaps no gasoline cars, as the vice mayor's proposal seemed to indicate. Moreover, it was in fact not at all clear that there would be a political majority in favour of an LEZ. At the time, Stockholm was ruled by a Social democrat/Left/Green party coalition. The transportation vice mayor represented the Green party, but it was unclear whether he had support for his proposal from his coalition partners.

${ }^{12}$ https://mitti.se/nyheter/daniel-hellden-dieselbil/

${ }^{13} \mathrm{https} / / / \mathrm{www}$.aftonbladet.se/bil/a/lqOM7/dieselforbud-sannolikt-i-stockholm

${ }^{14}$ https://www.dn.se/sthlm/dieselbilar-kan-forbjudas-i-stockholms-innerstad/ 
In March 2018, the government finally issued their amended legislation. The regulation of the LEZ was in fact made slightly less strict than the Transportation Agency's proposal. The LEZ regulation now required Euro 5 or higher until 2022 and Euro 6 thereafter. No mention was made of a complete diesel ban or of gradually making the regulation stricter. Cities were allowed to introduce an LEZ in an area of their own choice, but not before 2020 .

Gradually, as the general elections in September 2018 drew nearer, some other parties began to voice cautious opposition against the proposed LEZ in Stockholm. The Conservatives called the proposal "drastic", and promised not to introduce an LEZ "at least not as early as 2020 ". In June 2018, preliminary results from a Stockholm city report on costs, benefits and future emission levels (City of Stockholm, 2018) led the Social democrats to state that "an LEZ does not seem necessary". But considering that the parliamentary situation in Stockholm was anticipated to be very delicate, where the Green party would likely hold the balance of power between Social democrats and the four liberal/conservative parties, no party wanted to rule out an LEZ completely, since it was clear that this had become an important issue for the Green party in Stockholm.

In summary, the impression conveyed to the public between July 2017 and at least until the summer of 2018 was that an LEZ in Stockholm's inner city was very likely to be introduced, possibly banning all diesel cars at least eventually. This impression was established although the actual legislation in fact allowed Euro 6 diesels in the LEZ, that there was no political majority in favour of the LEZ, and that more and more politicians in the spring and summer of 2018 started to talk about LEZ:s only on certain streets rather than the entire inner city. The delicate parliamentary situation, the difficulty to understand obscure technical definitions of "emissions standards", and the fact that there was very little vocal opposition from other parties, meant that in the public debate and general news, the impression was still that Swedish car buyers should prepare for a complete diesel ban in Stockholm.

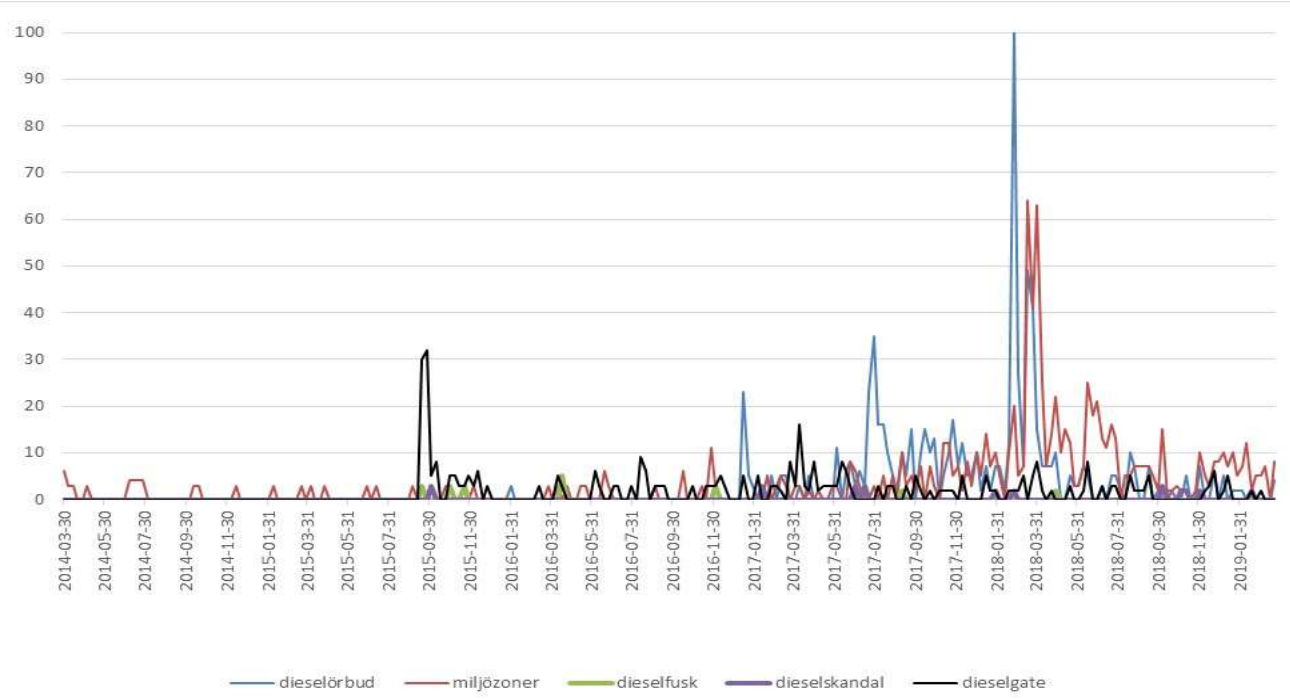

Figure 4: Interest over time in Sweden. Numbers represent Google search interest relative to the highest point on the chart for the given region and time. A value of 100 is the peak popularity for the term. A value of 50 means that the term is half as popular. A score of 0 means there was not enough data for this term.

In this paper we have studied the impact of the LEZ debate on prices for used cars and on sales of new cars. Since we wish to isolate the impact of the LEZ debate on prices and 
demands from other possible factors, a key issue is when the LEZ impact occurred. Figure 4 shows the relative number of Google searches in Sweden per week for the terms "diesel ban (dieselförbud)", "environmental zones (miljözoner)", "diesel cheating (dieselfusk)", "diesel scandal (dieselskandal)" and "dieselgate". As the figure shows, the interest for "diesel ban" and "environmental zones" started in earnest with the vice-mayor's proposal in July 2017 and peaked again when the government legislation was presented in March 2018. It can thus safely be assumed that prices and sales were not much affected by the LEZ debate before the summer of 2017.

The decreased demand for used as well as new compliant diesel cars might be caused by several different factors. First, it is possible that some got the impression from the debate that all diesel cars would be banned. Second, some might have anticipated that the LEZ regulation could later change to ban even later models of diesel cars. After all, both the city of Stockholm and the vice mayor of transportation had repeatedly stated that they wanted to tighten the regulation. Third, the arguments for an LEZ repeatedly emphasized the problems of diesel cars: how dangerous $\mathrm{NO}_{2}$ was for people's health and how real emissions were higher than laboratory values. This contributed to bad publicity by creating an image of diesel cars as "serious polluters", and this bad publicity may very well have affected the demand for diesel cars. After all, some years earlier, diesel cars were marketed as green cars because they are more energy efficient, and they probably became popular for that reason.

After the election in September 2018, the Green party changed political coalition from the left (Social democrats and the Left party) to the right (four liberal/conservative parties). In exchange, the Green party was allowed to introduce an LEZ in Stockholm starting in January 2020 - but only on a single street (Hornsgatan), rather than in the whole inner city. There are currently no plans to extend the LEZ to a larger area. Compliance with the LEZ regulation has been low so far: the share of banned cars on Hornsgatan has decreased from $23 \%$ before the LEZ (2019) to $18 \%$ with the LEZ (2020), and part of that decrease is likely due to natural renewal of the car fleet. The low compliance is probably associated with the mild enforcement: enforcement is supposed to be carried out by manual police inspections, but the police has stated that they prioritize other tasks.

\section{CONCLUSIONS AND POLICY ADVICE}

The primary motivation for low emission zones is to improve air quality. In this paper, we have presented a methodology for assessing the social costs of an LEZ for light vehicles. A main contribution is a development of a methodology for assessing the social cost in terms of drivers' welfare losses of an LEZ. The quantitative results are clearly associated with several sources of uncertainty. But we still think such results provides a contribution given that no prior literature has tried to assess them.

We find that the social costs of the proposed Stockholm LEZ covering the inner city are roughly ten times larger than the value of the health benefits. Social costs are high because a relatively large number of drivers are hurt, and a complete ban incurs a high cost for many individuals, evidently much higher than even a very high charge. We cannot empirically reveal how the consumer loss is distributed in the population. However, since less affluent households tend to own older cars and also have less access to company cars, a larger loss will probably accrue to them. Hence, it is likely that the LEZ would have a regressive distributional impact. 
The health benefits are relatively small for three reasons. First, Stockholm has relatively low atmospheric $\mathrm{NO}_{2}$ levels. Second, the natural vehicle renewal reduces health damaging emissions substantially also in the baseline in just a couple of years; light diesel vehicles with Euro 6d emission standard have much lower health damaging emissions. Third, the light vehicles that would be banned only contribute with a small share of $\mathrm{NO}_{2}$ levels; old heavy vehicles contribute more to those emissions and the LEZ for heavy vehicles in Stockholm is already scheduled to tighten gradually over time (and the number of heavy vehicles that are or will be banned are few compared to the millions of light vehicle owners affected by an LEZ for light traffic).

The relative size of social benefits and costs are likely to vary between cities and LEZ designs. In some cities the health benefit might be larger than the social costs. However, our main message is that it is a good idea to try and assess the costs and benefit before communicating a proposal. Not least because there is otherwise a risk of high cost incurred on car owners, particularly for owners of older cars that are often less affluent.

Our key policy advice to cities considering introducing LEZ for light vehicles to combat congestion and air pollution is to evaluate the costs and benefits carefully before communicating the policy to the public. Consider a charging system that is differentiated by emission levels rather than a ban. If going ahead and implementing an LEZ, it is advisable to announce it well in advance and be clear about the design and regulation of the zone and keep changes to a minimum to minimize the uncertainty and thereby adaptation costs. It should also be emphasized that new diesel vehicles emit much less NOx than older diesel cars and that they have lower carbon emissions than gasoline cars of equal size.

\section{ACKNOWLEDGEMENTS}

We are grateful to the anonymous reviewers, whose comments and suggestions have improved the paper substantially. We would like to thank Jonas Ericson (City of Stockholm) for help with vehicle fleet forecast assumptions and biofuel assumptions, and Christer Johansson, Lars Burman and their colleagues (SLB, City of Stockholm) for calculating weighted emission factors from HBEFA, NOx pollution levels and health effects.

\section{REFERENCES}

Amato, F., 2018. Non-Exhaust Emissions: An Urban Air Quality Problem for Public Health; Impact and Mitigation Measures. Academic Press.

Anenberg, S.C., Miller, J., Minjares, R., Du, L., Henze, D.K., Lacey, F., Malley, C.S., Emberson, L., Franco, V., Klimont, Z., Heyes, C., 2017. Impacts and mitigation of excess diesel-related $\mathrm{NO}_{x}$ emissions in 11 major vehicle markets. Nature 545, 467-471. https://doi.org/10.1038/nature22086

Atkinson, Richard.W., Butland, Barbara.K., Anderson, H.Ross., Maynard, Robert.L., 2018. Long-term Concentrations of Nitrogen Dioxide and Mortality. Epidemiology 29, 460-472. https://doi.org/10.1097/EDE.0000000000000847

Beelen, R., Raaschou-Nielsen, O., Stafoggia, M., Andersen, Z.J., Weinmayr, G., Hoffmann, B., Wolf, K., Samoli, E., Fischer, P., Nieuwenhuijsen, M., Vineis, P., Xun, W.W., Katsouyanni, K., Dimakopoulou, K., Oudin, A., Forsberg, B., Modig, L., Havulinna, A.S., Lanki, T., Turunen, A., Oftedal, B., Nystad, W., Nafstad, P., De Faire, U., Pedersen, N.L., Östenson, C.-G., Fratiglioni, L., Penell, J., Korek, M., Pershagen, G., Eriksen, K.T., Overvad, K., Ellermann, 
T., Eeftens, M., Peeters, P.H., Meliefste, K., Wang, M., Bueno-de-Mesquita, B., Sugiri, D., Krämer, U., Heinrich, J., de Hoogh, K., Key, T., Peters, A., Hampel, R., Concin, H., Nagel, G., Ineichen, A., Schaffner, E., Probst-Hensch, N., Künzli, N., Schindler, C., Schikowski, T., Adam, M., Phuleria, H., Vilier, A., Clavel-Chapelon, F., Declercq, C., Grioni, S., Krogh, V., Tsai, M.-Y., Ricceri, F., Sacerdote, C., Galassi, C., Migliore, E., Ranzi, A., Cesaroni, G., Badaloni, C., Forastiere, F., Tamayo, I., Amiano, P., Dorronsoro, M., Katsoulis, M., Trichopoulou, A., Brunekreef, B., Hoek, G., 2014. Effects of long-term exposure to air pollution on natural-cause mortality: an analysis of 22 European cohorts within the multicentre ESCAPE project. The Lancet 383, 785-795. https://doi.org/10.1016/S0140-6736(13)62158-3

Börjesson, M., Eliasson, J., Hugosson, M.B., Brundell-Freij, K., 2012. The Stockholm congestion charges - 5 years on. Effects, acceptability and lessons learnt. Transport Policy 20, 1-12. https://doi.org/10.1016/j.tranpol.2011.11.001

Börjesson, M., Kristoffersson, I., 2018. The Swedish congestion charges: Ten years on. Transportation Research Part A: Policy and Practice 107, 35-51. https://doi.org/10.1016/j.tra.2017.11.001

Brand, C., 2016. Beyond 'Dieselgate': Implications of unaccounted and future air pollutant emissions and energy use for cars in the United Kingdom. Energy Policy 97, 1-12. https://doi.org/10.1016/j.enpol.2016.06.036

Carslaw, D.C., Beevers, S.D., 2002. The efficacy of low emission zones in central London as a means of reducing nitrogen dioxide concentrations. Transportation Research Part D: Transport and Environment 7, 49-64. https://doi.org/10.1016/S1361-9209(01)00008-6

City of Stockholm, 2018. Effekter av miljözoner i Stockholms stad.

CLARS, 2019. Milano LEZ Area B. CLARS - Charging, Low Emission Zones, other Access Regulation Schemes. Supported by the European Commission [WWW Document]. Urban Access Regulations In Europe. URL https://urbanaccessregulations.eu/countries-mainmenu-147/italy-mainmenu81/milano-lez-area-b (accessed 9.15.19).

Eliasson, J., 2008. Lessons from the Stockholm congestion charging trial. Transport Policy 15, 395-404.

Ellison, R.B., Greaves, S.P., Hensher, D.A., 2013. Five years of London's low emission zone: Effects on vehicle fleet composition and air quality. Transportation Research Part D: Transport and Environment 23, 25-33. https://doi.org/10.1016/j.trd.2013.03.010

Energimyndigheten, 2019. Kontrollstation 2019 för reduktionsplikten. Reduktionspliktens utveckling 2021-2030.

Faustini, A., Rapp, R., Forastiere, F., 2014. Nitrogen dioxide and mortality: review and meta-analysis of long-term studies. European Respiratory Journal 44, 744 753. https://doi.org/10.1183/09031936.00114713

Holman, C., Harrison, R., Querol, X., 2015. Review of the efficacy of low emission zones to improve urban air quality in European cities. Atmospheric Environment 111, 161-169. https://doi.org/10.1016/j.atmosenv.2015.04.009

Johansson, C., Burman, L., Forsberg, B., 2009. The effects of congestions tax on air quality and health. Atmospheric Environment, Urban Air Quality 43, 48434854. https://doi.org/10.1016/j.atmosenv.2008.09.015

Johansson, C.S.G., Andersson, C., Bennet, C., Lars Gidhagen, Cyrys, J., Soentgen, J., $\mathrm{Gu}, \mathrm{J} ., 2$ 2014. Report on Low Emission and Congestion Charge Zones in Europe with impact assessment studies for Augsburg, Munich, Berlin and Stockholm. 
Lelieveld, J., Evans, J.S., Fnais, M., Giannadaki, D., Pozzer, A., 2015. The contribution of outdoor air pollution sources to premature mortality on a global scale. Nature 525, 367-371. https://doi.org/10.1038/nature15371

Malina, C., Scheffler, F., 2015. The impact of Low Emission Zones on particulate matter concentration and public health. Transportation Research Part A: Policy and Practice 77, 372-385. https://doi.org/10.1016/j.tra.2015.04.029

Morfeld, P., Groneberg, D.A., Spallek, M.F., 2014. Effectiveness of Low Emission Zones: Large Scale Analysis of Changes in Environmental NO2, NO and NOx Concentrations in 17 German Cities. PLOS ONE 9, e102999. https://doi.org/10.1371/journal.pone.0102999

Nafstad, P., Håheim Lund, L., Wisløff, T., Gram, F., Oftedal, B., Holme Ingar, Hjermann Ingvar, Leren Paul, 2004. Urban air pollution and mortality in a cohort of Norwegian men. Environmental Health Perspectives 112, 610-615. https://doi.org/10.1289/ehp.6684

O’Driscoll, R., Stettler, M.E.J., Molden, N., Oxley, T., ApSimon, H.M., 2018. Real world $\mathrm{CO} 2$ and NOx emissions from 149 Euro 5 and 6 diesel, gasoline and hybrid passenger cars. Science of The Total Environment 621, 282-290. https://doi.org/10.1016/j.scitotenv.2017.11.271

OECD, 2020. Non-exhaust Particulate Emissions from Road Transport. An Ignored Environmental Policy Challenge. OECD Publishing, Paris.

Pasquier, A., Andre, M., 2017. Decomposition of Low emission zone strategies into mechanisms and methodology for assessing their impacts on air pollution. Journal of Earth Sciences and Geotechnical Engineering 7, 241-261.

POLIS, Transport Decarbonisation Alliance, C40, 2020. How-to Guide on ZeroEmission Zones for Freight.

Silva Raquel A., Adelman Zachariah, Fry Meridith M., West J. Jason, 2016. The Impact of Individual Anthropogenic Emissions Sectors on the Global Burden of Human Mortality due to Ambient Air Pollution. Environmental Health Perspectives 124, 1776-1784. https://doi.org/10.1289/EHP177

SLB Analys, 2019. Luften i Stockholm 2018 (No. 17:2019), SLB-rapport. Miljöförvaltningen.

Swedish Energy Agency, 2019. DRIVMEDEL 2018. Redovisning av rapporterade uppgifter enligt drivmedelslagen, hållbarhetslagen och reduktionsplikten (No. 2019:14).

Swedish Energy Agency, 2018. Statens energimyndighetsförfattningssamling. STEMFS 2018:2.

Swedish Environmental Protection Agency, 2017. Bakgrund till de samhällsekonomiska schablonvärdena i miljömåls-myndigheternas gemensamma prisdatabas (No. 2017:8), Naturvårdsverket Rapport. Stockholm.

Trafikanalys, 2018. Vehicle kilometers 2017 (No. Statistik 2018:10).

Transport Analysis, 2017. Forecasts for vehicle fleet development in Sweden (Prognoser för fordonsflottansutveckling i Sverige) (No. 2017:8).

Transportstyrelsen, 2017. Miljözoner för lätta fordon (No. TSV 2015-4545). Transportstyrelsen.

Varian, H.R., 1992. Microeconomic Analysis.

Wolff, H., 2014. Keep Your Clunker in the Suburb: Low-Emission Zones and Adoption of Green Vehicles. Econ J 124, F481-F512. https://doi.org/10.1111/ecoj.12091 
Wolff, H., Perry, L., 2010. Policy MonitorTrends in Clean Air Legislation in Europe: Particulate Matter and Low Emission Zones. Rev Environ Econ Policy 4, 293 308. https://doi.org/10.1093/reep/req008 


\section{APPENDIX A}

Assuming a yearly driving cost of $13000 \mathrm{~km}$ per year ${ }^{15}$, the total additional yearly fuel cost for a new gasoline car is approximately $€ 400 .{ }^{16}$ A selection of the list price of ten common cars in Sweden indicates an extra capital cost of $€ 400$ - $€ 500$ per year for a diesel car compared to an equivalent gasoline car. ${ }^{17}$ Since the LEZ is not likely to have any major impact on tax revenues or consumer surplus, we assume that the total driving distance remains unchanged if a gasoline car replace a diesel car.

However, a shift from diesel to gasoline cars increases carbon emissions. A new gasoline car emits approximately $25 \%$ more carbon dioxide per kilometre than a diesel car of equal size (O'Driscoll et al., 2018). We neglect possible other external costs arising from higher NOx emissions from diesel to gasoline cars because the NOx emissions from Euro $6 \mathrm{~d}$ standard diesel car is small.

Table 7 shows how the effect on carbon emissions is computed. To assess the impact on car sales of the LEZ debate we take the forecast issued in April 2017 as the baseline (column A). In 2018, the sales of new gasoline cars were 8 percentage points higher than the baseline ( $48 \%$ compared to $40 \%$ in the baseline forecast). The share of hybrid and electric cars was $15 \%$ in 2018, which is only one percentage point lower than the baseline. For this reason, we assume that the 8 percentage points higher sales of gasoline cars over the baseline stems from lower sales of new diesel cars due to the LEZ, and that the 8 percentage points higher sales persist until the LEZ introduction 2022. In the main analysis we further assume that from year 2022, the market shares revert linearly back towards the baseline, and fully match the baseline by year 2030 (column B). We base this assumption on the possibility that by 2022 it becomes more widely known that new diesel cars (Euro 6d standard) emit much less NOx than the older fleet of diesel cars, and that car owners gradually assume that the LEZ regulation will not become stricter. However, this is a conservative assumption. In a sensitivity analysis we instead assume that the decrease in diesel car sales, compared to the baseline, persists until 2030.

Our conservative assumption in the main analysis leads to the estimate that 233000 new cars sold during 2017-2030 in Sweden (column C) would be additional gasoline cars instead of new diesel cars. Based on the 2017 Swedish car fleet, we assume that cars have an average life of 17 years, such that the additional gasoline cars accumulate over time (column D). The additional gasoline cars in the fleet changes over the years for two reasons: first because the number of replaced cars among the newly sold cars changes over time, and second because replaced diesel cars from previous years accumulates over time. The average driving distance per year (average for diesel and gasoline cars) is $16000 \mathrm{~km}$ for cars 8 years and younger, and $100000 \mathrm{~km}$ per car older than 8 years (Trafikanalys, 2018). The average driving distance per replaced car is in column E.

Column $\mathrm{H}$ shows the total effect on carbon emissions, assuming that a new medium sized diesel car in 2018 emits approximately $0.15 \mathrm{~kg} \mathrm{CO} / \mathrm{km}$ and gasoline cars $0.19 \mathrm{~kg}$

\footnotetext{
${ }^{15}$ Because of the lower fuel cost and higher fixed cost (capital cost and yearly vehicle tax), a selection mechanism result in the average driving distance for diesel cars being on average 83 percent higher than for gasoline cars. However, we use the total average driving distance for gasoline and diesel cars, since this is likely to apply to the cars on the margin to change from diesel to gasoline.

16 Assuming that the gasoline cars use 65 I per $100 \mathrm{~km}$ and a gasoline car uses 45 I per $100 \mathrm{~km}$. We assume that these figures stay constant for new cars over future years.

17 The list prices indicate an extra yearly capital cost of $€ 200-€ 300$ for the diesel car, if assuming that it is paid over 10 years and interest rate $4 \%$. In addition, diesel car owners pay on average roughly $€ 200$ more per year in vehicle tax.
} 
$\mathrm{CO}_{2} / \mathrm{km} .{ }^{18}$ We assume that the emission levels remain constant over time. Summing up the effect over time we find that total increase in $\mathrm{CO}_{2}$ emissions is approximately 2 million tons, over the period 2017 to 2045 . As a comparison, this is equivalent to $90 \%$ of all carbon emissions from transport in the Stockholm City in 2017 and 13\% of all carbon emissions from road transport in Sweden in 2017.

The effect on carbon emissions computed so far does not consider that diesel fuel in Sweden contains a larger and rapidly increasing share of biofuel than gasoline fuel does. This is driven by the Swedish renewable energy directive (reduktionsplikt) requiring that biofuels are mixed into fossil fuels such that their carbon emissions decrease by at least $19.3 \%$ in delivered diesel and by $2.6 \%$ in delivered gasoline up until 2020. The share of biofuels in delivered diesel and gasoline must be even higher, as production of biofuel give rise to carbon dioxide emissions. ${ }^{19}$ The share is higher for diesel because the supply of biofuels compatible with gasoline engines is more constrained than the supply biofuels compatible with diesel engines. The reduction levels until 2030 are not yet decided but we use the levels that the Swedish Energy Agency (2019) recommends the government, shown in column $\mathrm{F}$ and $\mathrm{G}$ for gasoline and diesel, respectively.

Column $\mathrm{H}$ shows the effect on carbon emissions if considering the higher share of biofuel in diesel, finding that the total increase in carbon increases to 3.5 million tons over the period 2017 to 2045. This implies a net present value of increased carbon emissions of -322 million $€$, assuming that the valuation of carbon increases by $1.5 \%$ annually and applying a social discount rate of 3.5\%. In the case where sales of diesel/gasoline cars do not revert to the baseline trend after 2022, the increase of $\mathrm{CO} 2$ emissions are approximately 5.6 million tons (or 3.4 tons under the assumption that no biofuels are mixed in the fuel).

Table 7: Costs and benefits of the shift from new diesel to gasoline cars.

\begin{tabular}{|c|c|c|c|c|c|c|c|c|c|}
\hline & A & B & $\mathrm{C}$ & D & $E$ & 1 & $\mathrm{~F}$ & G & $\mathrm{H}$ \\
\hline Year & $\begin{array}{l}\text { Baseline } \\
\text { share of } \\
\text { gasoline } \\
\text { cars of } \\
\text { new cars } \\
\text { sales } \\
\%\end{array}$ & $\begin{array}{c}\text { Share of } \\
\text { gasoline } \\
\text { cars of } \\
\text { new cars } \\
\text { sales in } \\
\text { LEZ } \\
\text { scenario } \\
\%\end{array}$ & $\begin{array}{l}\text { Addi- } \\
\text { tional } \\
\text { yearly } \\
\text { sales of } \\
\text { gasoline } \\
\text { cars in } \\
\text { response } \\
\text { to LEZ }\end{array}$ & $\begin{array}{l}\text { Cum. } \\
\text { addi- } \\
\text { tional } \\
\text { gasoline } \\
\text { cars in } \\
\text { response } \\
\text { to LEZ }\end{array}$ & $\begin{array}{l}\text { Average } \\
\text { distance } \\
\text { per car } \\
(000 \mathrm{~km})\end{array}$ & $\begin{array}{l}\text { Increase } \\
\text { in CO2 } \\
\text { emission } \\
\text { assumin } \\
\text { g } 100 \% \\
\text { fossil } \\
\text { fuel } \\
\text { [kt] }\end{array}$ & $\begin{array}{c}\mathrm{CO} 2 \\
\text { relative } \\
\text { to fossil } \\
\text { due to } \\
\text { biofuel } \\
\text { gasoline } \\
(\%)\end{array}$ & $\begin{array}{l}\mathrm{CO} 2 \\
\text { relative } \\
\text { to fossil } \\
\text { due to } \\
\text { biofuel } \\
\text { diesel } \\
(\%)\end{array}$ & $\begin{array}{c}\text { Increase } \\
\text { in CO2 } \\
\text { emission } \\
20 \text { due } \\
\text { biofuel } \\
\text { [kt] }\end{array}$ \\
\hline 2018 & 40 & 48 & 28194 & 30434 & 16.0 & 20 & 97 & 81 & 32 \\
\hline 2019 & 39 & 47 & 28476 & 58910 & 16.0 & 38 & 97 & 80 & 62 \\
\hline 2020 & 37 & 45 & 28761 & 87671 & 16.0 & 56 & 97 & 80 & 93 \\
\hline 2021 & 36 & 44 & 29048 & 116719 & 16.0 & 75 & 94 & 75 & 123 \\
\hline 2022 & 36 & 43 & 25831 & 142550 & 16.0 & 91 & 92 & 72 & 154 \\
\hline 2023 & 36 & 41 & 22603 & 165153 & 16.0 & 106 & 89 & 68 & 182 \\
\hline 2024 & 35 & 40 & 19368 & 184521 & 16.0 & 118 & 87 & 64 & 208 \\
\hline 2025 & 35 & 39 & 16130 & 200651 & 16.0 & 128 & 85 & 60 & 230 \\
\hline 2026 & 34 & 38 & 12890 & 213542 & 15.9 & 130 & 83 & 56 & 237 \\
\hline 2027 & 34 & 36 & 9654 & 223195 & 15.1 & 129 & 80 & 52 & 240 \\
\hline 2028 & 33 & 35 & 6424 & 229619 & 14.4 & 126 & 78 & 48 & 239 \\
\hline 2029 & 33 & 34 & 3205 & 232824 & 13.7 & 121 & 75 & 44 & 234 \\
\hline 2030 & 32 & 32 & 0 & 232824 & 13.0 & 115 & 72 & 40 & 226 \\
\hline 2031 & & & & 232824 & 12.3 & 110 & 69 & 38 & 206 \\
\hline 2032 & & & & 232824 & 11.7 & 105 & 65 & 36 & 188 \\
\hline 2033 & & & & 232824 & 11.2 & 101 & 62 & 33 & 173 \\
\hline
\end{tabular}

${ }^{18}$ Assuming that the gasoline cars use 65 I per $100 \mathrm{~km}$ and a gasoline car uses $45 \mathrm{I}$ per $100 \mathrm{~km}$. The fuel consumption is derived from the $\mathrm{CO} 2$ emissions with fossil fuel, using energy conversion factors by Swedish Energy Agency (2018).

19 See the Swedish Energy Agency (2019) for the calculation of carbon emissions from biofuels.

${ }^{20}$ Assuming constant driving distance and that the $\mathrm{CO} 2$ emissions from a gasoline car is 0,19 tons/ $000 \mathrm{~km}$ and from a diesel car 0,15 tons $/ 000 \mathrm{~km}$ (corresponding to the emissions of medium sized new cars 2018). 


\begin{tabular}{|l|l|l|l|c|c|c|c|c|c|}
\hline 2034 & & & & 230583 & 10.8 & 97 & 58 & 31 & 157 \\
\hline 2035 & & & & 202389 & 10.5 & 83 & 55 & 29 & 128 \\
\hline 2036 & & & & 173913 & 10.3 & 70 & 51 & 27 & 102 \\
\hline 2037 & & & & 145153 & 10.1 & 58 & 48 & 25 & 79 \\
\hline 2038 & & & & 116105 & 10.0 & 46 & 44 & 22 & 59 \\
\hline 2039 & & & & 90274 & 10.0 & 36 & 41 & 20 & 43 \\
\hline 2040 & & & & 67671 & 10.0 & 27 & 37 & 18 & 30 \\
\hline 2041 & & & & 48302 & 10.0 & 19 & 34 & 16 & 20 \\
\hline 2042 & & & & 32172 & 10.0 & 13 & 30 & 14 & 12 \\
\hline 2043 & & & & 19282 & 10.0 & 8 & 26 & 11 & 6 \\
\hline 2044 & & & & 9628 & 10.0 & 4 & 23 & 9 & 3 \\
\hline 2045 & & & & 3205 & 10.0 & 1 & 19 & 7 & 1 \\
\hline SUM & & & 230583 & & & 2031 & & & 3466 \\
\hline
\end{tabular}

